\title{
Chapter 14 \\ Curriculum and Leadership in Transnational Reform Policy: A Discursive-Institutionalist Approach
}

\author{
Kirsten Sivesind and Ninni Wahlström
}

\begin{abstract}
Educational leadership research has in general focused on organizational conditions and expectations for managing and leading activities (Leithwood et al. 1994, pp. 38-61; Spillane and Healey 2010; Møller 2006, pp. 53-69) in parallel curriculum theories have offered insights into substantial societal problems that must be addressed in school and society (Hopmann 1999, pp. 89-105; Westbury 2000, pp. 15-54). This chapter presents a study in which we link curriculum theory both to discursive institutionalism and educational leadership policy and research findings. By including discursive institutionalism (Schmidt 2012) within a framework of curriculum theory, it is possible to distinguish between different forms of discourses and their functions in forming and conveying ideas. Thus, we explore educational leadership policy using a reflexive approach to reforms as intertwined with public discourses and research. A transnational perspective on leadership confirms the applicability of reforms across geographical territories, relating to wider societal and cultural contexts. Following an institutional-discursive approach, we argue that the ways in which social and educational questions become intertwined in actual reforms are dependent on cognitive and normative ideas in the public sphere. Thus, reforms to education leadership are related to coordinative and communicative discourses beyond the individual reform, while solutions to curriculum and leadership problems are anchored in educational policies and practices. Against this background, we argue that a deeper understanding of the meaning of educational leadership discourse and the conditions under which such a discourse is conducted is crucial.
\end{abstract}

\footnotetext{
K. Sivesind $(\bowtie)$

Department of Education, University of Oslo, Oslo, Norway

e-mail: kirsten.sivesind@iped.uio.no

N. Wahlström

Department of Education, Linnaeus University, Växjö, Sweden

e-mail: ninni.wahlstrom@lnu.se
} 


\section{Introduction}

Curriculum theory and leadership research reflect similar issues and problems, albeit based on different theoretical perspectives and origins. While curriculum theory is rooted in theories of education and society, educational leadership research takes as its starting point normative and cognitive models concerning organizations, situations, and persons. Moreover, the scientific orientation makes leadership research a useful recourse for political control across various sites and sectors. Our discourse analysis of 14 policy documents published by the EU (European Union), the OECD (the Organization for Economic Co-operation and Development), and various associated companies, demonstrates that the general and generic orientation of leadership models fits well with the overall ambitions and goals of transnational reform policy. Thus, educational leadership is regarded as an opportunity to improve the efficiency of transnational policy decisions and strategies, not least by reforming the tertiary education of school principals in the member countries. However, our main argument in this chapter is that there is a need to problematize the relationship between school leadership research, reform policy, education, and society. How are policy and leadership rooted in societal discourses? Can leadership models be applied in education without regard for curriculum issues and problems? How can these two fields, curriculum and leadership studies, learn from each other by promoting critical stances towards policy reform discourses?

There are three primary reasons for our suggestion of exploring how curriculum theory might contribute to educational leadership as a research field and as policy. First, the meaning of educational leadership is embedded within the larger context of transnational policy. Second, the meaning of educational leadership is deeply intertwined with ideological discourses on education at large, since this meaning cannot be distinguished from important curriculum matters related to teaching and learning in schools. Third, to fully understand the complexity of educational leadership, there is a need for a conceptual framework that takes ideology, structure, and actors into account. This implies a sensibility for sector-specific dimensions, which in our case relates to educational mandates, curriculum reform and the purposes of education.

Drawing on discursive institutionalism (Schmidt 2008, 2012), the purpose of this chapter is to introduce a framework for the analysis of transnational educational leadership policies that include underlying assumptions about society and education in general. First, we offer a short introduction to the history of the curriculum and leadership research fields in order to demonstrate the overlapping scopes and interests as well as the differences and relationships. We then introduce a discursiveinstitutionalist approach as a framework for the analysis of policy documents concerning educational leadership that addresses transnational problems and perspectives in the current school systems in Europe and beyond. Curriculum theory 
comes into the discussion as both a foundation for understanding how the perceptions of leadership as reflected in our documentation relate to institutional and societal ideas, and how policy- and research-based conceptions of leadership forms are attributable to programmatic ideas and norms within education (as illustrated in Table 14.1). Finally, we make use of the institutional framework to discuss (i) the ways in which the established discourses on educational leadership associated with curriculum problems are linked to the basic notions of community needs, (ii) how the transnational meaning of educational leadership is maintained through a coordinative discourse, and (iii) how this agreed meaning is promoted to the nation states through a communicative discourse.

\section{Curriculum Theory}

The long-standing issues of curriculum and reform have both been subject to extensive research over the years. In the field of curriculum studies, educational reform is above all analyzed according to the origin and institutionalization of public schooling, which has today developed into comprehensive education systems (Hopmann 2003; Lundgren 2003; Westbury 2003). The curriculum as a research field links the study of contemporary problems in education to the tradition of historiography and on to a large range of reflection theories that developed from the early nineteenth century onwards. Moreover, the field of curriculum research has primarily dealt with the history of educational ideas and the study of educational systems and institutions in which legislation and reforms have been a primary topic of study (Doyle 1992; Gundem 1994). However, contemporary researchers add new perspectives to the field by examining governmental changes across and within specific geographical territories and in relation to comparative and international studies that consider the uniqueness of the reforms to a wider societal and cultural context beyond the national (Sivesind and Karseth 2014). A traditional focus of curriculum research has been to examine the topical structure of teaching practices in the context of pedagogy and schooling (Hopmann 2007; Uljens 1997). In curriculum research, the policy and practice of schooling, as well as its programmatic dimensions, have been approached by research that draws on different theories and traditions. First, in the curriculum field, a major presupposition is that the curriculum, whether understood as a curricular framework, teaching material, or a course of study, relates to formalized and institutionalized modes of teaching practices that can be traced back to the pre-Renaissance (i.e., between 1000 and 1250) when schools were licensed by church authorities and not by the state (Hamilton 1989: 12-13). According to this perspective, the relevant ideas and concepts are related to the classical thinkers of Ancient Greece (Hopmann 1999; Lundgren 1979). Since that time, thoughts and 
theoretical distinctions are considered perennial, although they have undergone ground-breaking changes with reference to alterations to the education system and the surrounding society (Hopmann 1999; Schubert 1986; Westbury 2000). For this reason, curriculum theories serve as more than a source for empirical research on institutions, organizations or persons in various settings. Curriculum theories approach practical and moral problems of education, first of all by making use of ideological and societal perspectives to critically reflect upon core conditions and processes in education.

Second, the reconceptual approach became central to curriculum studies during the 1970s in both the American and European contexts. William Pinar stands out as a key researcher in this tradition (Pinar 1978), while Englund (1990) argues that this approach has also been the core idea of curriculum history research in Scandinavia and Europe. The main aim of this perspective has been to establish a critical response to historiography studies and empirical conceptual approaches, which were part of the prevailing tradition of curriculum studies in the Anglo-American field in the 1960s.

In the Scandinavian context, Lundgren (1972) examined several questions that were of political interest during the early 1970s, such as the consequences of dividing pupils into homogeneous versus heterogeneous school classes with respect to the differences in their learning achievements. He later called for increased attention to be paid to the political aspects of education along with a reconceptualizing approach. This position was inspired by British scholars, particularly Basil Bernstein and Michael Young, who both argued for a new direction for the sociology of education from the early 1970s (Bernstein 1971; Young 1971). The conceptual configuration of this "new direction" expresses what occurred during the 1970s as a theoretical shift. Formalized regulations and institutions were no longer viewed as the solution, but rather as the problem. Instead, research on the sociology of education focused on outcomes and the structures that could explain those outcomes. For example, the main goal for Young was to shift the focus from thinking of schooling as being determined by society to instead contributing to the determination of society (Young and Whitty 1977). This shift in perspective highlighted the potential to change society through education research.

The main viewpoint of the new sociologists was that knowledge is produced and reproduced by dominant groups in society and is, therefore, highly ideological and political in character. One major presumption of Bernstein's theory was that the school system favored pupils from the middle class over those from the working class, partly because of its way of structuring the use of language that contributes to a power dynamic. A vertical dimension connecting politics and schooling was introduced, and it conceptualized the curriculum as socially organized knowledge involving different kinds of interests (Young 1971). Later books and articles written by Bernstein (2000/1996) and Young (1998) centered on pedagogy, social discourse, and a recontextualized approach to identity and knowledge.

In recent decades, when curriculum standards entered the arena of educational reforms, they became a focus of attention too (Muller 2000). As a consequence, new research issues emerge within critical research that are informed by educational and 
societal perspectives (Sundberg and Wahlström 2012; Yates 2009; Young 2008). For this reason, curriculum theories serve as more than a source for empirical research on institutions, organizations or persons in various settings. Curriculum theories approach practical and moral problems of education, first of all by making use of ideological perspectives. However, later theories have integrated the formal and societal-discursive perspectives, as well as their materiality, to critically reflect upon core conditions and processes in education. From this point of view, structural reforms possess interpretive dimensions that must be considered according to practicalities, discretion, and sensibleness in policy, research, and practice. Nonetheless, the features of education cannot be comprehended as organizational categories alone, but are instead institutionalized within their societal environment (Menck 2000; Reid 1986, 1999).

At the beginning of the 2000s, a relevant question is how schooling as an institutionalized pursuit is challenged by the views of what counts as core units of analysis, such as competences and outcomes, compared with other kinds of purposes and pursuits, as part of the larger context of society. The interest in scientific approaches to reforming teaching in schools, which was followed by a constructivist approach to research and education, has also called for a stronger focus on the actors and systems and how they contribute to both the reproduction of society and the renewal of the education system. It is within this area, by framing our analysis within an institutional-discursive approach, that we can see an interface between curriculum theory and leadership research.

\section{Leadership Research}

Leadership research examines how various actors are influencing the work of others in order to accomplish certain goals. In school leadership research, the school principal stands out as the key actor within the school organization. For this reason, educational leadership research has traditionally placed emphasis on how the school principal performs a specific role and function within the school as an organization. The responsibility of school principals can be related to different tasks and duties within the schools, as well as to teaching, although the teachers have been considered to control the agency over classroom decisions. In educational leadership research, one strand of research focuses on management as the key concept characterizing what school principals do within their organizations, while another strand of research considers leadership as a broader concept, which includes not only administrative but also relational and human features.

Until recently, educational leadership studies have focused on how leaders conduct leadership through power relations, thereby influencing others within the context of the school organization. Based on theories from the larger field of organization studies, these studies can be broadly sketched by their orientation to traits, contingency, and transformational theories (Lingard et al. 2003). While traits theories 
regard leadership in light of personal dispositions and qualities as dependent on the style and capacity of the person who is leading an organization, contingency theories emphasize how styles and behaviors are adapted to particular situations. The leader is, in this case, expected to coordinate goals and activities, being the prime instigator of the delegation of tasks and responsibilities by regulating other people's mind sets and activities. Transformational leadership theories add the dimensions of vision and vision building to leadership studies. This perspective also integrates ideas regarding how transactions are played out by individuals, assuming that persons act rationally toward each other to achieve certain benefits from their involvement with organizations (Leithwood and Jantzi 2006). A more recent theoretical approach suggests that distributed leadership is a helpful perspective for studying how schools exercise informal power that goes beyond the boundaries of both formal responsibility and the school context. This perspective also invites discussion on what constitutes democratic leadership in light of the discursive and political aspects.

Educational researchers have stressed the importance of situational theories and site-based work. Noteworthy studies utilizing this approach have been conducted by Hallinger and Heck (2010), who argue that instructional leadership is dependent on the mutual influence between students' learning and school capacity, which is shaping and is shaped by the collective leadership that is conceptualized as school-wide actions. These actions involve actors such as principals, teachers, administrators, and others. Based on this approach, educational features, such as constructing a school curriculum, are not separated from school leadership but are essentially a part of it (Hallinger 2010). Further, instructional leadership is seen as encouraging transformation, not merely by normative means but by developing the organization's cognitive capacity to select its purposes and support the development of instructional practices. This approach includes an interest in curriculum matters and school cultures, as well as the ways in which schools are capable of fostering high expectations for learning. Not only first-order change is highlighted, wherein technologies or persons directly regulate the work of students and teachers, but also a second-order phenomenon, whereby the school conditions and the climate require persons to change their actions within the organization (Hallinger 2003, p. 338). Consequently, instructional leadership is thought to exert both a direct and an indirect influence on individuals' actions and activities within the school organization.

In transformational leadership theories, common goals and shared visions serve as a key focus Thus, the shaping of the ideologies of members of an organization is a key issue in these studies (Leithwood 1994). The attention paid to goals is also important for examining transactional leadership as different from, or simply as an aspect of, transformational leadership. To examine how leaders and their followers exchange gratifications in order to achieve the best results, rational choice theories are built into these research approaches (Bass 1997, 1999; Burns 1978). Researchers who adopt this position often refer to empirical evidence to support their arguments concerning how such transactions make an impact on the processes within school organizations as well as their outcomes (Leithwood and Jantzi 2006; Leithwood et al. 1994; Oterkiil and Ertesvåg 2014). One consequence of this research approach 
is the study of particular factors that might explain the actions and priorities of the actors involved, such as the significance of a school's leadership, in terms of teachers' resilience. Day and Gu's (2010) study of effective and trusting relationships within organizations demonstrates that a school's leadership is actually regarded as the most important factor for organizational resilience, which supports transformational and transactional theories (see also Mulford (2003)).

In recent years, within school leadership research, as well as in national and local policy making, a distributive perspective on school leadership has aroused intense interest. A distributive view of leadership recognizes that leading schools can involve multiple individuals in addition to the school principal- "the leader-plus aspect"-and that leading a school is fundamentally concerned with interactions rather than about the actions of individual leaders- "the practice aspect" (Spillane and Healey 2010). According to Harris (2007), this view of distributed leadership rests on an idea of leadership as cognition. Research on distributed leadership is characterized by an interest in opening up new perspectives on the question of who can take part and who can be counted on when studying leadership practices. For example, Woods et al. (2004) understand distributed leadership as an emergent property of a group or network of interacting individuals operating within an unlimited space in which distributed expertise extends the boundaries by going beyond the formal functions of an organization. It has been argued that distributed leadership does not necessarily guarantee democratic processes and practices because it does not explain who is in control of whom and on what premise; therefore, it is suggested that there is a need to integrate sociological theories into discussions about the complexity of organizations and leadership studies (Gronn 2009). In the debate regarding democratic leadership, Lingard et al. (2003) argue that educational leadership must acknowledge complexity, diversity, and equity as salient characteristics in the formal leadership task of every school principal. Based on this perspective, the democratic features are specifically taken into consideration, and they have also been the focus of several studies on educational leadership within the Scandinavian context (Johansson 2001; Moos et al. 2004; Møller 2006). However, the political/democratic aspects of leadership practices cannot be viewed as merely being generated by a single leader and leadership practices in schools. This argument has led to sociological and critical-oriented studies that seek to interpret leadership as an aspect of policy formation related to the democratic problems of society (Gunter 2012; Møller and Skedsmo 2013).

This brief overview of the leadership theories indicates that educational leadership research represents a diverse field that would benefit from a theoretical framework with the ability to simultaneously capture the societal and ideological policy level and the different dimensions of the governance of institutionalized education. From both an instructional and a transformational perspective, and based upon the most recent discussion on distributed perspectives, it becomes clear that a deep understanding of the context of educational reform and policy changes is as important as an awareness of the relevant actions of school leaders, teachers, and others who are involved in school leadership. Moreover, comparing the field of theories in leadership research and transnational policy, we see an urgent need for self-reflection 
on the ways in which leadership definitions are included in the justification of policy. In light of curriculum theory, there seem to be several overlapping policies and practices between the research fields (Uljens and Ylimaki 2015). However, the understanding of educational leadership as it is described in articles and textbooks risks being either too general-that is, there is no distinction between leading a school or leading other social practices (see Young 2008) — or too restricted-that is, each school/district is considered to be its own independent unit.

We thus suggest that the meaning of educational leadership needs to be conceptualized by means of an institutional multilevel analysis, whereby transnational educational policy formations, as well as national governing discourses, curriculum problems, and local school leadership practices, are taken into consideration. In the following section, we turn to the theory of discursive institutionalism to frame our analysis into an integrative approach linking transnational policies on educational leadership to curriculum theories and problems. Our aim is to create a framework through which educational leadership can relate to curriculum theory, including the wider societal/ideological perspectives that are helpful in understanding the discourse of educational leadership. By this, we will not enter into the field of educational practices, but will instead examine the policy level within a transnational policy discourse.

\section{A Theoretical Framework: Discursive Institutionalism and Curriculum Theory}

Discursive institutionalism is a collective term for exploring the content of ideas and the interactive processes that are reflected through discourses in institutional contexts. This fourth version of the new institutionalism approach is focused on both the theorizing of the substantive content of cognitive and normative ideas and the interactive discursive processes and argumentation by which these ideas are produced, conveyed, and potentially lead to collective actions (Schmidt 2012).

Schmidt (2012) argues that agents within institutions possess two forms of abilities: background ideational abilities and foreground discursive abilities. Schmidt (2012) interprets background ideational abilities as a human capacity to understand and structure the environment from know-how concerning how the known world works. Human background ideational abilities allow actors inside and outside institutions to speak and think about institutions in certain ways, thereby contributing to both creating and maintaining institutions through collective discursive actions. Discourses work simultaneously at two levels in institutions. The background ideational abilities represent an everyday level of communication within and about the institution. The foreground discursive abilities, conversely, comprise actions when people distance themselves from the everyday institutional activities and discuss and reflect on the institution at a more general level, which also involves reflection and change from an "outside" perspective. Thus, the foreground discursive abilities 
provide the basis for a coordinative discourse that is characterized by the creation, elaboration, and justification of a certain policy. They also provide the basis for a communicative discourse that takes the ideas and policies outside the institution to "the public" for discussion and deliberation. The public here includes political actors, media, interest groups, and ordinary citizens who can act on and contribute to the discourse by engaging in the discussion (Schmidt 2012).

Discursive institutionalism distinguishes between two types of ideas: cognitive and normative. Cognitive ideas offer solutions to the problems at hand and represent the reasoning for what should be done and why. They include proposals, suggestions, guidelines, and so on that are based on what should be done upon consideration of the circumstances; that is, they express "necessary" actions that are evoked by certain causes and logic. Normative ideas, contrastingly, offer values as the bases for cognitive ideas. They add values to policy actions and policy solutions, and they legitimate policy with reference to normative values and ideologies. If cognitive ideas are legitimized by factual causes, normative ideas are argued for in terms of more general values (Schmidt 2008).

By combining the levels of cognitive and normative ideas with coordinative and communicative discourses, it becomes possible to analyze questions regarding when and where educational discourses on school leadership matter, who is setting the agenda, and to whom the agenda is communicated. When a special meaning that is embedded in a specific material context is translated to another context, it opens it up to a "discursive gap." This gap constitutes a space for the production of discourse through the recontextualization of meanings; that is to say, when a discourse moves away from its original site and into a new arena, a transformation occurs by means of which different elements of meaning within the discourse are selectively appropriated, relocated, refocused, and so on. Although elements of the discourse can be recognized, it is not totally the same discourse anymore, since possibilities for partly new meanings have been created through the transformation from one arena to another. The construction of policy discourses and educational leadership discourses can be understood as processes recontextualizing discourses by moving between different arenas, thereby reinterpreting certain dominant concepts of a discourse (Bernstein 2000/1996).

\section{The Policy Documents: Data and Analysis}

Discursive institutionalism as a research strand helps to classify groups of statements in policy documentation that articulate how actors approach formal and substantive aspects of societal fields as well as their communicative character. In our study, we selected policy documents from the EU and the OECD, which we expected to reflect a transnational discourse on education reform policy beyond the national level. By initially screening a cluster of policy documents that we downloaded from the EU and OECD websites, referred by national authorities in our own countries 
(i.e., Sweden and Norway), we selected a total of 14 documents that articulated meaning concerning the ways in which leadership makes sense as part of reform policy within and across national contexts. Thus, in our examination of the documents, we conducted a qualitative study that sought to unravel their meaning (Coffey 2014, p. 8) as well as the discourses this meaning related to. Discourses were then thought of as "an ensemble of ideas, concepts, and categories through which meaning is given to social and physical phenomena, and which is produced and reproduced through an identifiable set of practices" (Hajer 2003, p. 300).

To avoid a biased selection of documents compared to the existing corpus of policy documents published by the two organizations, we compared the reference lists between the documents and we made use of a snowball method by checking for other documents concerning leadership and leadership research that were mentioned within the papers. In this way, we could trace the ideas and discourses using a forward and backward tracing strategy, utilizing references in one document as pointers to other documents and thereby constructing a text corpus.

The documents were examined with regard to theory and, at the same time, informed by the narrative descriptions that we condensed in order to generate images of what was written about leadership, leadership research, and reform policy. The narrative descriptions were constructed by the use of a technique for identifying themes (Ryan and Bernard 2003). The themes were discovered by reading through the selected documents and clustering expressions in light of the theoretical perspectives framed by an institutional-discursive theory. Dimensions such as spheres, normative and cognitive ideas, and coordinative and communicative discourses guided our reading of the documents and thereby our means of identifying and categorizing themes. By analyzing the themes and the narrative descriptions, as condensed by re-reading the documents, we were also able to point out ways in which leadership and leadership research were conceptualized within the discourses of reform policy for each of the fields and levels included in our study. Thus, we did not apply an evaluative approach to study the documents, but rather an interpretative point of view, for the sake of developing analytical perspectives and theories (Kuckartz 2014). In order to make the theoretical and deductive dimensions transparent, we will present the core concepts and perspectives of Schmidt's (2012) theory. However, our core purpose is not merely to make use of this theory in a deductive way, but with regard to the documents, to conduct an analysis that helps to renew perspectives on curriculum and leadership research.

In terms of discursive institutionalism, Schmidt (2012) distinguishes between three different spheres, although for this study only the first two are relevant. The public philosophy sphere represents a basic sphere of public worldviews and assumptions that underpin the policy solutions, although these assumptions are seldom consciously formulated or even recognized. Instead, they form a background for the sphere of programmatic ideas. The public philosophy sphere generally includes two forms of ideas: normative ideas and cognitive ideas. Normative ideas are concerned with legitimizing policy programs that express the suggested solutions by referring to how they are rooted in a deeper understanding of the world. Cognitive ideas are instead concerned with the interpretation of these background 
assumptions in the public philosophy sphere in order to define the problems to be solved and identify the solutions to be used in the programmatic sphere. The sphere of programmatic ideas consists of a more general program that functions as a common frame of reference for ideas, actions, and solutions that are suggested as possible responses to a problem. This sphere is characterized by its foreground position, which means that ideas and suggestions are debated and discussed on a regular basis.

The spheres of discursive institutionalism are broadly in line with the levels of analysis that are generally suggested within curriculum theory: a societal/ideological arena in which basic assumptions regarding the needs of a society and ideas about education are formed, and a programmatic arena that represents the actual concrete policy documents proposed. A third level of analysis points to the so-called classroom level, where the suggested policy solutions are interpreted and performed in local practice (Deng and Luke 2008; Lundgren 1979). By combining these arenas with the public philosophy sphere and the sphere of programmatic ideas of policy formation, discursive institutionalism contributes to curriculum theory with a more elaborate tool of analysis capable of distinguishing between cognitive and normative ideas, as well as between coordinated and communicative discourses.

In this chapter, the focus of the analysis is transnational educational leadership policy. Therefore, only the first two spheres or arenas are relevant to this study. The analytical interpretive framework combines concepts and meaning from discursive institutionalism and curriculum theory via an analysis of leadership discourses emerging in transnational policy documents. An overview of the combined framework for the present study is presented in Table 14.1 below (see also Wahlström \& Sundberg 2017).

Table 14.1 The framework of analysis and the links between the perspectives in discursive institutionalism, curriculum theory, and leadership discourses

\begin{tabular}{l|l|l|l}
\hline Transnational arenas & $\begin{array}{l}\text { Discursive } \\
\text { institutionalism }\end{array}$ & Curriculum theory & $\begin{array}{l}\text { Leadership } \\
\text { discourses }\end{array}$ \\
\hline The societal/institutional realm & $\begin{array}{l}\text { Public } \\
\text { philosophy }\end{array}$ & $\begin{array}{l}\text { Institutional/societal } \\
\text { ideas }\end{array}$ & $\begin{array}{l}\text { Organizational } \\
\text { theories }\end{array}$ \\
\cline { 2 - 4 } & $\begin{array}{l}\text { Normative and } \\
\text { cognitive ideas } \\
\text { about society } \\
\text { and education }\end{array}$ & $\begin{array}{l}\text { Basic assumptions } \\
\text { concerning society and } \\
\text { education }\end{array}$ & $\begin{array}{l}\text { General ideas of } \\
\text { the need for } \\
\text { leadership in } \\
\text { schools }\end{array}$ \\
\hline The programmatic realm & $\begin{array}{l}\text { Programmatic } \\
\text { ideas }\end{array}$ & $\begin{array}{l}\text { Programmatic ideas } \\
\text { and norms }\end{array}$ & $\begin{array}{l}\text { Programmatic } \\
\text { models }\end{array}$ \\
\cline { 2 - 4 } & $\begin{array}{l}\text { Coordinative } \\
\text { and } \\
\text { communicative } \\
\text { discourses }\end{array}$ & $\begin{array}{l}\text { Common policy } \\
\text { understanding and } \\
\text { recommendations to } \\
\text { reform education }\end{array}$ & $\begin{array}{l}\text { Policy- and } \\
\text { research-based } \\
\text { suggestions for } \\
\text { the type of } \\
\text { leadership } \\
\text { needed }\end{array}$ \\
\hline
\end{tabular}




\section{Societal Ideas and Programmatic Discourses on Educational Leadership in the Transnational Arena}

In this section, we present the results of the analysis in terms of the normative and cognitive ideas in the sphere of public philosophy on education in general and on school leadership in particular. Further, we report on coordinated as well as communicative discourses concerning educational leadership in the field of programmatic ideas.

\section{Public Philosophy: Ideas and Assumptions Concerning Education and Educational Leadership}

Often in policy texts, the references and justifications in the overarching discourse refer to "the rapidly changing world." This is also true for the overall discourse on education and school leadership. At a very general level, the basic assumption can be formulated as in the following example:

Across the globe, the 21 st century is seeing rapid economic and social change. Social and population mobility allied with technological advances and an increased focus on schools to perform mean that students today face very different challenges from their predecessors (Pont et al. 2008b, p. 3).

Together, these changes are assumed to alter the role of schools, as well as the role of school leaders, in fundamental ways. Three distinctive implications of the current challenges for education in relation to leadership can be noticed in the OECD's argumentation: (i) school autonomy, (ii) school accountability, and (iii) school leadership going beyond the individual school. With the increased autonomy of schools comes the increased autonomy of school leaders. Therefore, school autonomy is closely linked to school accountability in terms of student performance, for which school leaders are, in turn, ultimately responsible. The school leaders are also supposed to take on a broader responsibility, including for other schools and the local community in terms of a system-wide school improvement. The aim of this form of school leadership is to develop what the OECD refers to as system leadership. It is linked to a normative idea of a learning organization. Further, system leadership, with its systemic focus, is assumed to have the potential to contribute to system transformation (Pont et al. 2008a). However, system leadership can only exercise influence in relation to the degree to which it is focused on teaching and learning. Thus, a coordinated discourse of system leadership opens up programmatic discourses of personal leadership (as "system thinkers"), of distributed leadership, as well as of instructional leadership. The cognitive idea of the need for leadership of the school itself is never questioned in these transnational policy documents. Instead, the interest is focused on the meaning of education leadership in a rapidly changing world. A cognitive answer to this challenge is that educational 
leaders need to take on a new role as system leaders in a broader understanding of leadership. The cognitive idea is that only if school leaders are both working close to their own school and with other schools and school leaders, caring for the success of both their own and other schools, can they contribute to changing the whole system to be more effective and successful in terms of results.

The belief that it is necessary to change the school system as a whole is related to another basic cognitive idea of the effect of education on economic growth. Within this set of cognitive ideas, human capital is a core concept (Boarini et al. 2012). The way in which the OECD deals with this issue, for example, is to relate students' skills, as measured by the Programme for International Student Assessment (PISA), to economic growth by means of recent economic modeling. The OECD's conclusion is that if each member state boosts its average PISA scores by 25 points over the next 20 years, there will be "an aggregate gain of OECD GDP of USD 115 trillion over the lifetime of the generation born in 2010" (OECD 2010, p. 6). A similar idea was expressed in the Lisbon Strategy by the EU in 2000: "The Union has today set itself a new strategic goal for the next decade: to become the most competitive and dynamic knowledge-based economy in the world"' (European Council 2000 , p. 2, italics in original).

To meet the demands for change, the main normative idea in the transnational arena is that of continuous learning from cradle to grave. In the discourse on lifelong learning, "competence" is a key concept. The identified competences are supposed to express the individual ability that is needed to meet the complex demands created by globalization and modernization in an increasingly interconnected world characterized by diversity. Both the OECD and the EU have formulated frameworks of key competencies, and both systems of competencies are measured by the PISA surveys (European Commission 2007, 2013; Rychen and Salganik 2005). The idea of lifelong learning also implies that school leaders need to develop effective leadership skills for leading learning communities. By implementing the frameworks of key competencies, both the OECD, through the PISA surveys, and the EU (European Council 2000), through the Open Method of Coordination (OMC), have the normative tools for monitoring and evaluating their member states' adaptations of a framework for lifelong learning.

\section{Programmatic Ideas of Education and Leadership in the Transnational Policy Arena}

Programmatic ideas about education and school leadership in the transnational policy arena are analyzed by examining the coordinative and communicative discourses of educational leadership. On the transnational programmatic level, ideas of curriculum are incorporated in a technical- instrumental coordinated discourse. The technical-instrumental curriculum discourse is characterized by the assumption that curricula ought to be designed in accordance with economic and labor market 
related demands. It is in light of this discourse that the emergence of performancebased and standards-based reforms can be understood because of their ability to measure "knowledge outcomes" in a seemingly comparable way (Sundberg and Wahlström 2012).

\section{A Coordinative Discourse of Effective Leadership}

The "Rethinking Education" program, which was launched by the EU in 2012, argued for the importance of member states investing in education and skills training as the most valuable tool for increasing Europe's competitiveness and productivity (European Commission 2012a). It is noted that school leaders spend more than $40 \%$ of their time on management and administrative activities. It is also noted that the number of applications for school leadership posts is often very low in the member states. The European Commission states that educational leadership is second only to teaching among the school-related factors that determine the outcomes of students' learning (European Commission 2012b, p. 43). The quality of school leadership is believed to affect both the motivation of teaching staff and the quality of their teaching. It is argued that the PISA results are higher in countries in which teachers are held accountable to school leaders and to external inspectors through the monitoring of lessons. The school leaders' impact on the ethos of the school is also believed to be significant (European Commission 2012b). In a policy discourse in which efficiency and equity are placed at the foreground of education, school leaders are at the intersection of educational policy and its implications at the school level. The efficiency discourse emphasizes teachers' motivation, skills, and competences as key factors for achieving high quality learning outcomes; in turn, the quality of educational leadership is an essential factor for achieving the goal of good teaching with an ability to inspire all students and make them all want to learn. What is referred to as "effective school leadership" is viewed as crucial for shaping an effective environment for teaching and learning - a learning environment with high aspirations that are supported by appropriate organizational structures and a good school climate. Two factors are highlighted in the efficiency discourse for school leaders: first, it is of key importance to ensure that school leaders are not overburdened with administrative work; and, second, it is important to ensure that school leaders have the capacities and qualities needed to handle an increasing number of very diverse tasks (European Council 2009). The coordinative discourse is consistent with a discourse of transformational leadership research, which expresses the purpose of leadership as motivating followers to work toward common goals. The leaders need to use their charisma and their ability to inspire their staff (Leithwood 1994; Leithwood and Jantzi 2006). In later texts, instructional leadership and managerial leadership have been subsumed within the overall concept of transformational leadership. Transformational leadership has a clear connection to the policy-based and neoliberal concept of New Public Management (Hall et al. 2013), and its representatives argue that it is possible to find correlation between 
transformational leadership and student outcomes (e.g. Sun and Leithwood 2012). Basically, transformational leadership promotes a role for the education leader as a "lonely hero" leading the team toward common goals to improve the school, although advocates of this leadership conception have also tried to go beyond a onesided, individually shaped leadership. In the coordinative discourse there is, however, still a strong normative idea about who can take on a role as principal, what set of central skills he or she needs to have, and that, in the end, the success of the school is dependent on the abilities of its principal.

\section{Communicative Discourses: Implementing Policies}

The policy slogan of getting the right people to be principals has gained lot of media attention in recent years. The motto is also echoed in other policy documents from the OECD (2013) and the private sector (Barber and Mourshed 2007; Mourshed et al. 2010), and it mirrors the individual leadership expressed in the coordinating discourse above. The slogan summarizes a political understanding of leadership against which the communicated leadership discourses on the programmatic arena are reflected.

The McKinsey report from 2007 comprised several simple solutions for school systems that want to reach the top of the results table, including advice concerning educational leadership. It is all about "getting the right people to become school leaders," providing "these people with the right set of skills," and structuring "the roles, expectations and incentives to ensure that its principals focus on instructional leadership, not on school administration" (Barber and Mourshed 2007, p. 30). In this efficiency discourse, the "right" school leader is him- or herself an excellent instructor who spends his or her time coaching the teachers to become better instructors and, as a consequence of this coaching, improves the teachers' ability to increase the students' achievements. The ideal principal is a person who focuses on helping the teachers to learn from each other, a person who is constantly spending time out in the classrooms and halls among the students, and a person who engages in e-mails and administration only after everyone else has left the school for the day. On the other hand, in a follow-up study, the need to support the school leader with a school system that includes adequate administrative staff is emphasized to ensure that the principal can focus on educational leadership. The ideal in this subsequent report is rather the "collective capacity" that is reached when teachers and school leaders work together to examine "what works" and to improve instruction together (Mourshed et al. 2010). In these two examples of the efficiency discourse on educational leadership, the message is addressed directly to the national policy arena. This is a discourse that is pre-eminently interconnected with a standards-based curriculum format because the leadership logic is based on the premise that "good" education leadership manifests itself in improved knowledge results. According to the EU (2012a), EU reforms have streamlined curricula across the EU by introducing standardized tests and infrastructure for literacy, mathematics, and science centers. 
Thus, the ideal of education leadership needs to be interpreted in close relation to the promotion of standards-based curriculum reform at a programmatic transnational level.

Furthermore, the policy text has the character of a decontextualized manual: if you act like this, your national school system will improve regardless of where in the world you are. In the two reports referred to above, a displacement from an individually to a more collective leadership ideal can be discerned. Stated otherwise, in the programmatic arena the communicative discourse is moving from an individual to a distributed leadership discourse, although still remaining within a normative idea of system leadership and learning in organizations as well as within a coordinative discourse of transformational leadership.

Based on references to current research within the field of education leadership, the OECD also communicates a discourse of distributed educational leadership for schools. The assumption is that effective leadership does not need to be exclusively related to one or a few formal positions; rather, it can be distributed across a number of individuals and teams in the school. According to the OECD (Pont et al. 2008a), the "increased responsibilities and accountability of school leadership are creating the need for distribution of leadership, both within schools and across schools." In accordance with this formulation, distributive leadership can be understood as part of the "system leadership" concept, formed in the field of cognitive ideas in the societal/institutional arena. In the same vein, the European Commission (2012b) argues that the core competencies for educational leadership can be supported by policy, for example, the impact of the principal tends to be stronger where the degree of school autonomy is higher. The Commission defines the core competencies as the ability to have vision and to be able to inspire others, to think strategically, to enhance learning environments and learning cultures, to improve the quality of students' learning and their learning outcomes, to manage resources effectively, to have good knowledge of the school system, to have strong communication skills, and to be able to solve problems. While all of those competencies can be said to represent systemic skills, the Commission also believes that successful education leadership requires specific personal characteristics. "School leadership staff are also likely to be most effective if they possess personal attributes such as courage, optimism, resilience, tolerance, emotional intelligence, self-awareness, energy, ambition, commitment and a desire for learning" (European Commission 2012b, p. 46). As school leaders are given greater responsibility for their school's academic achievement, the EU urges their member states to promote distributed leadership as a route to school improvement. A collaborative approach to leadership includes a "greater degree of networking and mutual learning between school leaders at local, national and European level" to promote "self-reflection, encourage further professional development, facilitate mutual support, disseminate policy and practice ... and mitigate some of the effects of between-school competition" (European Commission 2012b, p. 51).

So far, there have been strong links between personal (transformational) leadership and collective (distributed) leadership in the programmatic ideas of the transnational policy arena. There is a clear communicative discourse advocating that 
although a distributed leadership is increasingly favored, a collective leadership still needs to be led by a charismatic leader with a multitude of requested characteristics. At the same time as both individual and collective leadership represent two strong, intertwined conceptions of leadership in education policy documents, there is also a third theme of leadership in the communicative discourse. In 2013, the OECD published an expert report that outlined the concept of "learning leadership" as a distinct new concept of leadership compared with, for example, instructional leadership and leadership for learning. It is emphasized that learning is a basic starting point for educational leadership policy. "As learning is the core business of education, it provides the paramount form and purpose of leadership focused on creating and sustaining environments that are conducive to good learning" (OECD 2013, p. 9). This approach is fully in line with the normative idea of lifelong learning as a public philosophy in the societal arena:

...learning leadership is specifically focused on the design, implementation and sustainability of innovative, powerful learning environments through distributed, connected activity and relationships of a range of formal and informal leaders throughout a learning system (OECD 2013, p. 9).

Learning leadership builds on earlier findings concerning the importance of school autonomy, distributed leadership, and leadership as the path to school improvement. In fact, the latter is specifically emphasized in the claim that leadership is highly influential for learning and outcomes at all levels of the school system. The interest is centered on leadership itself, which means that all those included in a distributed leadership are affected, not only those who hold formal positions. The purpose of a learning leadership is to shape the conditions for "deep learning" to take place, in contrast to a merely instrumental view of learning. It is about creating innovative learning environments adapted to the challenges of the twenty-first century, calling for leaders "to be creative, thinking differently, and taking risks as they push themselves out of their comfort zones and experiment with developing and implementing new designs and encouraging others to do the same without fear of failure" (OECD 2013, p. 23).

Even if the basic analysis is still the same, leadership has an important impact on school results and so that leadership needs to be distributed to many. The requirements have now been increased and the demand of an innovative learning leadership implies that leaders are expected to continuously put themselves at stake. This approach is echoed in a curriculum strategy emphasizing that countries should "foster entrepreneurial skills through new and creative ways of teaching and learning" and focus on "the opportunity of business creation as a career destination" (European Commission 2012a, p. 4). The communicative discourse of both education leadership and curriculum expresses dissatisfaction with a school that is perceived to be too traditional and poorly adapted to the current requirements of the global labor market. Though the innovative approach is highlighted and it characterizes the discourse by introducing a partly new way of talking about leadership, the original purpose of the improvement of students' outcomes is still intact. In this "new" discourse, leadership is spoken of as dominated "by the relatively enclosed world of 
formal schooling"; a learning leadership can, however, "open horizons" and explore what leadership means in "complex environments that mix different players, settings, and styles" (OECD 2013, p. 14).

The concept of leadership that emphasizes "to lead" as well as to distribute a collective leadership is related to the modernization of the public sector in terms of the New Public Management (NPM). During the same period, distributed leadership has also aroused a considerable interest within educational leadership research. Gunter et al. (2013, p. 559) use the term "functional" to designate approaches that focus on "removing dysfunctions from the system, particularly in globalizing economy where governments have adapted modernizing accountability processes." The term "normative" expresses a desire to change and improve practice. A functionalnormative perspective of distributed leadership thus represents research that provides findings that form the basis for specifically designed national leadership reforms with the purpose of promoting good practice, or the so-called evidencebased policy initiatives. The research orientation is related to the research fields of school improvement and school effectiveness, with international organizations such as the OECD and the EU acting as mediators. The research within this field claims that the principal cannot lead the school alone; instead, the principal needs to share the leadership with others. It is argued that research makes it possible to identify the best way in terms of how and to whom the leadership should be distributed, which leads to practical advice concerning the leadership factors affecting the school and its outcomes in a positive direction (Gunter et al. 2013).

\section{Educational Reform, School Improvement, and Leadership}

In this study, we have linked curriculum theory to discursive institutionalism and to educational leadership policy and research. Curriculum theory is helpful for illustrating how policy formations are recontextualized in different transnational and national arenas. We demonstrate how different actors, both governmental organizations and private multinational companies, form coordinated horizontal discourses of what it means to be a "good" leader. By including discursive institutionalism within a framework of curriculum theory, it becomes possible to distinguish between different forms of discourses and their different functions in forming and conveying ideas (Schmidt 2012). Coordinative discourses are nourished by ideas available in the public philosophy of a society through the elusive phenomenon of the "public spirit." Such a strong normative vision of the overarching international arena is the idea of lifelong learning and the need for all citizens to learn throughout their lives.

A dominant cognitive idea on the societal international level concerning educational leadership is that schools need to have principals and that those principals have the ability to affect the outcomes of the school. The transnational perspective on leadership confirms the presence of reforms as travelling across geographical territories relating to wider societal and cultural contexts (Steiner-Khamsi 2013). The basic supposition is that when society changes rapidly in terms of its commu- 
nication and migration patterns, the principal also needs to go beyond his/her own school and exercise leadership in a wider system in order to change and transform the school in a more powerful way (Pont et al. 2008b).

These normative and cognitive societal ideas about lifelong learning and system leadership are reflected in the transnational discourse coordinated between different international actors on a programmatic level. There is a common understanding of educational leadership as being exerted by an individual person capable of leading followers toward common goals for an improved school. The focus on improved results requires a common transnational policy of a standards-based curriculum with predetermined goals and standardized national and international tests (Sundberg and Wahlström 2012). From this coordinated vision, there has been a gradual displacement towards a distributed leadership involving both formal and informal leaders of the school (Leithwood and Jantzi 2006; Lingard et al. 2003; Spillane and Healey 2010); however, the image of the impact of the leader from a transformational leadership concept is still very tangible within a distributive understanding of leadership in policy documents.

A collective view of leadership develops to be the dominant coordinative discourse, and from this common base of distributed leadership, three different communicative discourses of functional-normative beliefs (Gunter et al. 2013) about leadership can be distinguished. There is a strong discourse of getting "the right person" to be a leader linked to a transformational leadership (Barber and Mourshed 2007). However, there is also strong advocating for a distributed leadership, not least from the OECD (Pont et al. 2008a, b). More recently, as if neither the transformational nor the distributed leadership has been able to offer enough force to seriously challenge and improve the school system, a learning leadership has been introduced (OECD 2013). The latter has close connotations to innovation and "thinking outside the box," manifested through the language used within this orientation of leadership. Learning leadership is not a new form of leadership, but rather it is a variation of distributed leadership developed into network formations and experimentalism to provoke the system from within. The suggested solution for improving learning and knowledge results in schools is to keep the focus exclusively on learning, leaving other institutional commitments aside. Learning leadership can be said to illustrate a well-known truth within curriculum theory, namely that it is not easy to get reforms to deliver the expected results (Karabel and Halsey 1977; Lundgren 2006). In educational leadership policy and in much of the research on leadership, the expectations of the results of school reforms and school improvements are placed on the shoulders of principals as the central actors in schools (Barber and Mourshed 2007; Mourshed et al. 2010; OECD 2013; Pont et al. 2008a, b).

By relating leadership research to communicative transnational discourses of educational leadership policy, it seems clear that certain international research and transnational policy initiatives can be viewed as symbiotic. In particular, the functional-normative orientation of distributive leadership is developed in close connection to the policy needs of evidence-informed recommendations concerning factors expected to contribute to improved educational outcomes. However, as this 
chapter has shown, both societal and educational issues are crucial in reform policy, as well as the formal, substantive, and discursive dimensions. Following an institutional-discursive approach, we will argue that the ways in which social and educational questions become intertwined in actual reforms are dependent on cognitive and normative ideas in the public sphere. Thus, reforms to education leadership are related to coordinative and communicative discourses beyond the individual reform, while solutions to curriculum and leadership problems are anchored in educational policies and practices.

Against this background, we argue that a deeper understanding of the meaning of educational leadership discourse and the conditions under which such a discourse is conducted is crucial. While educational leadership research has so far focused on the organizational conditions and expectations for managing and leading activities, curriculum theories have offered insights into societal and educational problems to be dealt with in school and in society. We suggest taking both fields into consideration in future policies and practices; however, not without a reflexivity around how reform and research are intertwined. It is with this ambition in mind that we have approached curriculum and leadership from a discursive-institutionalist perspective.

\section{References}

Barber, M., \& Mourshed, M. (2007). How the world's best-performing school systems come ut on ttop. New York: McKinsey \& Company.

Bass, B. M. (1997). Does the transactional-transformational leadership paradigm transcend organizational and national boundaries? American Psychologist, 52(2), 130-139.

Bass, B. M. (1999). Two decades of research and development in transformational leadership. European Journal of Work and Organizational Psychology, 8(1), 9-32.

Bernstein, B. (1971). On the classification and framing of educational knowledge. In M. F. D. Young (Ed.), Knowledge and control: New directions for the sociology of education (pp. 47-69). London: Collier MacMillan Publishers.

Bernstein, B. (2000/1996). Pedagogy, symbolic control and identity: Theory, research, critique (rev. ed.). Lanham: Rowman \& Littlefield.

Boarini, R, d'Ercole, M. M., \& Liu, G. (2012). Approaches to measuring the stock of human capital: A review of country practices. http:/www.oecd-ilibrary.org/economics/ approaches-to-measuring-the-stock-of-human-capital_5k8zlm5bc3ns-en

Burns, J. (1978). Leadership. NY: Harper \& Row.

Coffey, A. (2014). Analysing documents. The SAGE handbook of qualitative data analysis. SAGE Publications Ltd. In U. Flick (Ed.), The Sage handbook of qualitative data analysis (pp. 367380). London: SAGE Publications Ltd..

Day, C., \& Gu, Q. (2010). The new lives of teachers. London: Routledge.

Deng, Z., \& Luke, A. (2008). Subject matter: Defining and theorizing shcool subjects. In F. Michael Connelly, M. F. He, \& J. A. Phillion (Eds.), The Sage handbook of curriculum and instruction (pp. 66-87). Los Angeles: Sage Publications.

Doyle, W. (1992). Curriculum and pedagogy. In P. W. Jackson (Ed.), Handbook of research on curriculum (pp. 497-516). New York: Macmillan Publishing Company.

Englund, T. (1990). Curriculum history reconsidered. Scandinavian Journal of Educational Research, 34(2), 91-102. 
European Commission. (2007). Key competences for lifelong learning-European reference framework. (Vol. 25). Luxembourg: Office for Official Publications of the European Communities.

European Commission. (2012a). Rethinking education: Investing in skills for better socioeconomic outcomes. Communication from the Comission to the European Parliamanet, the Council, the European Economic and Social Commitee and the Commitee of Regions, COM. 669 final. Strasbourg: European Comission.

European Commission. (2012b). Supporing the teaching professions for better learning outcomes. Accompanying the document "Rethinking education: Investing in skills for better socio-economic outcomes" Comission staff working document. SWD. 374 final. Strasbourg: European Comission.

European Commission. (2013). PISA 2012: EU performance and first inferences regarding education and training policies in Europe. Brussels: Directorate- general for Education and Culture.

European Council. (2000). Presidency conclusions: European Council, Lisbon, 23 and 24 March 2000. http://www.europarl.europa.eu/summits/lis1_en.htm

European Council. (2009). Council conclusions of 26 November 2009 on the Professional Development of Teachers and School Leaders. Official Journal 2009/C 302/04. Brussels: European Council.

Gronn, P. (2009). Leadership configurations. Leadership, 5(3), 381-394. doi:10.1177/1742715009337770.

Gundem, B. B. (1994). Curriculum: The history of. In T. Husén \& T. Neville Postlethwaite (Eds.), The international encyclopedia of education (Vol. 2, pp. 1301-1308). New York: Pergamon Press.

Gunter, H. M. (2012). Leadership and the reform of education. Bristol: The Policy Press.

Gunter, H., Hall, D., \& Bragg, J. (2013). Distributed leadership: A study in knowledge production. Educational Management Administration \& Leadership, 41(5), 555-580. doi:10.1177/1741143213488586.

Hajer, M. A. (2003). Coalitions, practices, and meaning in environmental politics: From acid rain to BCE. In D. R. Howarth \& J. Torfing (Eds.), Discourse theory in European politics (pp. 297 314). London: Palgrave Macmillan.

Hall, D., Gunter, H., \& Bragg, J. (2013). Leadership, new public management and the re-modelling and regulation of teacher identities. International Journal of Leadership in Education, 16(2), 173-190.

Hallinger, P. (2003). Leading educational change: Reflections on the practice of instructional and transformational leadership. Cambridge Journal of Education, 33(3), 329-352. doi:10.1080/0 305764032000122005.

Hallinger, P. (2010). Developing instructional leadership. In B. Daavis \& M. Brundrett (Eds.), Developing successful leadership (Vol. 11, pp. 61-76). Dordrecht: Springer.

Hallinger, P., \& Heck, R. H. (2010). Collaborative leadership and school improvement: Understanding the impact on school capacity and student learning. School Leadership \& Management, 30(2), 95-110. doi:10.1080/13632431003663214.

Hamilton, D. (1989). Towards a theory of schooling. London: The Falmer Press.

Harris,A. (2007).Distributed leadership:Conceptual confusion andempirical reticence.International Journal of Leadership in Education, 10(3), 315-325. doi:10.1080/13603120701257313.

Hopmann, S. T. (1999). The curriculum as a standard of public education. In Studies in philosophy and education (Vol. 18, pp. 89-105). Dordrecht: Kluwer Academic Publishers.

Hopmann, S. T. (2003). On the evaluation of curriculum reforms. Journal of Curriculum Studies, 35(4), 459-478.

Hopmann, S. T. (2007). Restrained teaching: The common core of Didaktik. European Educational Research Journal, 6(2), 109-124.

Johansson, O. (2001). Swedish school leadership in transition: In search of a democratic, learning and communicative leadership? Pedagogy Culture \& Society, 9(3), 387-406. doi:10.1080/14681360100200122. 
Karabel, J., \& Halsey, A. H. (1977). Power and ideology in education. New York: Oxford University Press.

Kuckartz, U. (2014). Three basic methods of qualitative text analysis. QSAGE Publications Ltd. In U. Kuckartz (Ed.), Quatlitative text analysis: A guide to methods, practice \& using software (pp. 65-121). London: SAGE Publications Ltd..

Leithwood, K. (1994). Leadership for school restructuring. Educational Administration Quarterly, 30(4), 498-518.

Leithwood, K., \& Jantzi, D. (2006). Transformational school leadership for large-scale reform: Effects on students, teachers, and their classroom practices. School Effectiveness and School Improvement, 17(2), 201-227. doi:10.1080/09243450600565829.

Leithwood, K., Menzies, T., \& Jantzi, D. (1994). Earning teachers' commitment to curriculum reform. Peabody Journal of Education, 69(4), 38-61. doi:10.2307/1492691.

Lingard, B., Hayes, D., \& Mills, M. (2003). Leading learning: Making hope practical in schools: Making hope practical in schools. Maidenhead: McGraw-Hill Education (UK).

Lundgren, U. P. (1972). Frame factors and the teaching process. A contribution to curriculum theory and theory on teaching. Stockholm: Almqvist og Wiksell.

Lundgren, U. P. (1979). Att organisera omvärlden. En introduktion till läroplansteori. Vällingby: Liber Förlag.

Lundgren, U. P. (2003). The political governing (Governance) of education and evaluation. In P. Haug, \& T. A. Schwandt (Eds.), Evaluating educational reforms: Scandinavian reforms (pp. 99-110). Information Age Publishing.

Lundgren, Ulf P. (2006). Political governing and curriculum change - From active to reactive curriculum reforms. The need for a reorientation of curriculum theory. Studies in Educational Policy and Educational Philosophy, 1, 1-12. Utdanningspolitiska Institutet http://www.upi. artisan.se/docs/Doc262.pdf

Menck, P. (2000). Looking into classrooms: Papers on Didactics. Stamford: Ablex Publishing Corporation.

Møller, J. (2006). Democratic schooling in Norway: Implications for leadership in practice. Leadership and Policy in Schools, 5, 53-69.

Møller, J., \& Skedsmo, G. (2013). Modernising education: New public management reform in the Norwegian education system. Journal of Educational Administration and History, 45(4), 336-353. doi:10.1080/00220620.2013.822353.

Moos, L., Möller, J., \& Johansson, O. (2004). A Scandinavian perspective on educational leadership. The Educational Forum, 68(3), 200-210. doi:10.1080/00131720408984632.

Mourshed, M., Chijioke, C., \& Barber, M. (2010). How the world's most improved school systems keep getting better. New York: McKinsey London.

Mulford, B. (2003). School leaders: Challenging roles and impact on teacher and school effectivenes. Paris: Comissioned Paper by the Educationand Training Policy division, OECD, for the Activity "Attracting, Developing and Retaining Effective Teachers".

Muller, J. (2000). Reclaiming knowledge: Social theory, curriculum, and education policy (Knowledge, identity, and school life series 8). London: Routledge.

OECD. (2010). The high cost of low educational performance: The long-run economic impact of improving PISA outcomes. The High Cost of Low Educational Performance. http://www.oecd. org/pisa/44417824.pdf

OECD. (2013). Leadership for 21 st century learning. Paris: OECD (Organisation For Economic, Co-Operation Development) Publishing.

Oterkiil, C., \& Ertesvåg, S. K. (2014). Development of a measurement for transformational and transactional leadership in schools taking on a school-based intervention. Educational Management Administration \& Leadership, 42 (4 suppl), 5-27. doi:10.1177/1741143214523011.

Pinar, W. F. (1978). The reconceptualization of curriculum studies. Journal of Curriculum Studies, 10(3), 205-214. 
Pont, Beatriz, Nusche, Deborah, \& Hopkins, David. (2008a). Improving school leadership, volume 1 case studies on system leadership: Case studies on system leadership, (Vol. 2). OECD Publishing.

Pont, B., Nusche, D., \& Moorman, H. (2008b). Improving school leadership: Volume 2, Case studies on system leadership. Paris: Organisation for Economic Co-operation and Development.

Reid, W. (1986). Curriculum theory and curriculum change: What can we learn from history? Journal of Curriculum Studies, 18(2), 159-166.

Reid, W. A. (1999). Curriculum as institution and practice. Essays in the deliberative tradition. London: Lawrence Erlbaum Associates, Publishers.

Ryan, G. W., \& Bernard, H. R. (2003). Techniques to identify themes. Field Methods, 15(1), 85-109. doi:10.1177/1525822x02239569.

Rychen, DS, \& Salganik, LH. (2005). The definition and selection of key competencies: Executive summary (Vol. 1).

Schmidt, V. A. (2008). Discursive institutionalism: The explanatory power of ideas and discourse. Annual Review of Political Science, 11(1), 303-326. doi:10.1146/annurev. polisci.11.060606.135342.

Schmidt, V. A. (2012). Scope, dynamics, and philosophical underpinnings. In F. Fischer \& J. Forester (Eds.), The argumentative turn revisited: Public policy as communicative practice (p. 85). Durham: Duke University Press.

Schubert, W. H. (1986). Curriculum. perspective, paradigm, and possibility. New York: Macmillan Publishing Company.

Sivesind, K., \& Karseth, B. (2014). Curriculum theory and research in Norway: Traditions, trends, and topics. International handbook of curriculum research (pp. 362-375). Lawrence Erlbaum Associates.

Spillane, J. P., \& Healey, K. (2010). Conceptualizing school leadership and management from a distributed perspective: An exploration of some study operations and measures. The Elementary School Journal, 111(2), 253-281.

Steiner-Khamsi, G. (2013). What is wrong with the 'What-Went-Right' approach in educational policy? European Educational Research Journal, 12(1).

Sun, J., \& Leithwood, K. (2012). Transformational school leadership effects on student achievement. Leadership and Policy in Schools, 11(4), 418-451.

Sundberg, D., \& Wahlström, N. (2012). Standards-based curricula in a denationalised conception of education: The case of Sweden. European Education Research Journal, 11(3).

Uljens, M. (1997). School didactics and learning: A school didactic model framing an analysis of pedagogical implications of learning theory. Hove: Psychology Press.

Uljens, M., \& Ylimaki, R. (2015). Towards a discursive and non-affirmative framework for curriculum studies, Didaktik and educational leadership. Nordic Journal of Studies in Educational Policy, 2015(3), 30177. doi:10.3402/nstep.v1.30177.

Westbury, I. (2000). Teaching as a reflective practice: What might Didaktik teach curriculum? In I. Westbury, S. Hopmann, \& K. Riquarts (Eds.), Teaching as a reflectice practice. The German Didaktik Tradition (pp. 15-54). London: Lawrence Erlbaum Associates, Publishers.

Westbury, I. (2003). Evaluating a national curriculum reform. In P. Haug \& T. A. Schwandt (Eds.), Evaluating educational reforms: Scandinavian perspectives. Greenwich: Information Age Publishing.

Woods, P. A., Bennett, N., Harvey, J. A., \& Wise, C. (2004). Variabilities and dualities in distributed leadership findings from a systematic literature review. Educational Management Administration \& Leadership, 32(4), 439-457.

Yates, L. (2009). From curriculum to pedagogy and back again: Knowledge, the person and the changing world. Pedagogy, Culture \& Society, 17(1), 17-28. doi:10.1080/14681360902742837.

Young, M. F. D. (Ed.). (1971). Knowledge and control: New directions for the sociology of education. London: Collier Macmillan Publishers.

Young, M. F. D. (1998). The Curriculum of the future: From the "New sociology of education" to $a$ "Critical theory of learning". London: Falmer Press. 
Young, M. F. D. (2008). From constructivism to realism in the sociology of the curriculum. Review of Research in Education, 32(2008), 1-28.

Young, M. F. D., \& Whitty, G. (Eds.). (1977). Society, state and schooling. Readings on the possibilities for radical education. London: The Falmer Press.

Wahlström, N., \& Sundberg, D. (2017). Discursive institutionalism: Towards a framework for analysing the relation between policy and curriculum. Journal of Education Policy, 1-21. http:// dx.doi.org/10.1080/02680939.2017.1344879

Open Access This chapter is licensed under the terms of the Creative Commons Attribution 4.0 International License (http://creativecommons.org/licenses/by/4.0/), which permits use, sharing, adaptation, distribution and reproduction in any medium or format, as long as you give appropriate credit to the original author(s) and the source, provide a link to the Creative Commons license and indicate if changes were made.

The images or other third party material in this chapter are included in the chapter's Creative Commons license, unless indicated otherwise in a credit line to the material. If material is not included in the chapter's Creative Commons license and your intended use is not permitted by statutory regulation or exceeds the permitted use, you will need to obtain permission directly from the copyright holder.

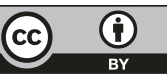

